\title{
Identifikasi profil antropometri dan pemenuhan zat gizi atlet difabel tenis meja di Indonesia
}

\author{
Mirza Hapsari Sakti Titis Penggalih ${ }^{1}$ *, Kurnia Maratus Solichah ${ }^{1}$, Diana Pratiwi ${ }^{1}$, Ibtidau \\ Niamilah $^{1}$, Mustika Cahya Nirmala Dewinta ${ }^{1}$, Almira Nadia ${ }^{1}$, Marina Dyah Kusumawati ${ }^{2}$, \\ Christofer Siagian ${ }^{2}$, Rora Asyulia ${ }^{2}$ \\ ${ }^{1}$ Departemen Gizi Kesehatan, Fakultas Kedokteran Universitas Gadjah Mada. \\ Jalan Farmako Sekip Utara, Yogyakarta 55281, Indonesia \\ ${ }^{2}$ Kementrian Pemuda dan Olahraga. Jalan Gerbang Pemuda No. 3; Jakarta Pusat 10270, Indonesia \\ * Corresponding Author. E-mail: mirza_hapsari@yahoo.com
}

Received: 8 September 2017; Revised: 2 March 2018; Accepted: 27 November 2018

\begin{abstract}
Abstrak
Tujuan penelitian ini untuk mengetahui dan mengidentifikasi profil antropometri dan pemenuhan asupan zat gizi pada atlet difabel tenis meja. Metode yang digunakan pada studi ini adalah deskriptif kuantitatif. Populasi dalam penelitian ini yaitu atlet difabel tenis meja di bawah pengawasan Kementerian Pemuda dan Olahraga, Indonesia yang sedang melakukan training centre untuk persiapan Sea Games 2017. Sampel yang diikutkan dalam penelitian ini yaitu seluruh populasi atlet difabel tenis meja nasional yang berjumlah 16 orang. Data antropometri yang diukur yaitu tinggi badan, berat badan, persen lemak tubuh dan somatotipe. Data pemenuhan asupan zat gizi didapatkan melalui wawancara makan dengan kuesioner recall 24 jam. Pengukuran antropometri menunjukan bahwa atlet tenis meja laki-laki memiliki tubuh yang lebih tinggi dan berotot, sedangkan atlet perempuan cenderung lebih banyak presentase lemak tubuh. Hal ini didukung dengan nilai persen lemak tubuh atlet perempuan dan komponen somatotipe bagian endomorf yang lebih tinggi, sedangkan komponen somatotipe mesomorf yang menunjukkan otot lebih tinggi pada atlet laki-laki. Nilai rata-rata pengukuran somatotipe laki-laki dan perempuan yaitu 6,3-3,4-2,0 dan 6,1-4,6-1,4. Nilai ektomorf lebih rendah berkaitan dengan disabilitas yang dialami, dimana otot bagian kaki tidak digunakan sehingga tidak berkembang. Rata-rata pemenuhan asupan zat gizi makro pada atlet tenis meja laki-laki dan perempuan diketahui $<80 \%$ yang masuk dalam kategori pemenuhan asupan makan yang kurang.
\end{abstract}

Kata Kunci: antropometri, energi, karbohidrat, protein, lemak, para-atlet, tenis meja.

\section{Identification of anthropometry and dietary profile on table tennis para- athlete in Indonesia}

\begin{abstract}
The aim of this study is to identify the anthropometry dan dietary profile on table tennis paraathlete. The study used quantitative descriptive methods. Population of this study is table tennis paraathlete under supervision of Ministry of Youth and Sports on training centre for Sea Games 2017. Samples that were included in this study were all of 16 table tennis national para-athletes. Measurements of atnthropometry included height, weight, body fat and somatotype. Measurement of dietary intake was done using food recall 24 hours questionnaire. Anthropometry measurement shows that male athletes have a higher and lots of muscle posture while female athletes have more body fat. The data also shows that value of endomorf somatotype and percent body fat on female athletes were higher than male athletes. The average value of somatotype are 6.3-3.4-2.0 for male and 6.1-4.6-1.4 for female athletes. Dietary intake consisted of energy, carbohydrate, protein and fat shows $<80 \%$ of the normal range which means inadequat intake of daily food.
\end{abstract}

Keywords: anthropometry, energy, carbohydrate, protein, fat, para-athlete, table tennis.

How to Cite: Penggalih, M., Solichah, K., Pratiwi, D., Niamilah, I., Dewinta, M., Nadia, A., Kusumawati, M., Siagian, C., \& Asyulia, R. (2018). Identifikasi profil antropometri dan pemenuhan zat gizi atlet difabel tenis meja di Indonesia. Jurnal Keolahragaan, 6(2), 162-171. doi:https://doi.org/10.21831/jk.v6i2.15676

https://doi.org/10.21831/jk.v6i2.15676 


\section{PENDAHULUAN}

Atlet difabel merupakan seseorang yang menggeluti satu cabang olahraga tertentu tetapi memiliki keterbatasan fisik. Keterbatasan fisik tersebut bisa didapatkan bawaan dari lahir, kecelakaan maupun karena sakit. Adanya disabilitas pada kondisi fisik ini menyebabkan setiap cabang olahraga memiliki kategori masing-masing sesuai dengan keterbatasan fisik atlet. Tenis meja merupakan salah satu cabang olahraga yang memiliki penyesuaian bagi atlet difabel yaitu atlet yang tidak dapat berdiri dapat bertanding dengan menggunakan kursi roda.

Olahraga net sport merupakan cabang olahraga yang menggunakan net dan raket dalam permainannya sehingga cabang olahraga ini juga dikenal sebagai cabang 73 olahraga racquet sport. Olahraga ini merupakan salah satu cabang olahraga popular yang dimainkan di berbagai negara, baik bersifat professional maupun rekreasional. Contoh olahraga ini adalah bulu tangkis, tenis, tenis meja, squash dan lainnya. Olahraga ini dapat dimainkan di lapangan, seperti bulu tangkis, dan tenis, maupun dengan menggunakan media seperti meja yaitu tenis meja, dan dinding, yaitu squash. Penguasaan teknik yang baik, kecepatan, konsentrasi, dan strategi merupakan kunci dari olahraga tersebut. Serangan yang bersifat mendadak serta durasi pertandingan yang tidak dapat diprediksi membuat atlet cabang olahraga ini membutuhkan stamina serta endurance yang baik (Maughan, 2008, p. 632).

Para-tenis meja dibagi menjadi 11 kelas dengan rincian kelas 1-5 diperuntukan bagi atlet yang bertanding dengan kursi roda. Kelas 1 dengan kondisi terburuk dan kelas 5 dengan kondisi disabilitas yang semakin ringan. Kelas 610 diperuntukan bagi para-atlet yang bisa bergerak atau berdiri (tanpa kursi roda). Kelas 6 adalah kategori bagi atlet dengan kondisi disabilitas paling buruk. Kelas 11 diperuntukkan bagi atlet yang mengalami keterbatasan intelektual.

Tenis meja menuntut setiap atlet normal maupun difabel memiliki 4 karakteristik yang harus dimiliki yaitu taktik, teknik, fisik dan psikologi yang optimal. Keseluruhan karakteristik yang optimal mendukung output performa yang maksimal saat bertanding (Kovacs, 2007, p. 189). Limoochi menuliskan hasil studinya bahwa penilaian pelatih saat penyeleksian atlet pada poin antropometri dan somatotipe tubuh mencakup $44,4 \%$ sedangkan sisanya melihat pada aspek psikologi, motorik dan psikomotor atlet (Limoochi, 2012, p. 21).

Pemenuhan asupan makan atlet menjadi satu masalah yang masih dialami oleh atlet. Penggalih dalam disertasinya menyebutkan bahwa tingkat pemenuhan zat gizi atlet profesional di Indonesia masih termasuk dalam kategori kurang untuk energi, karbohidrat dan protein sedangkan pemenuhan lemak berlebih (Penggalih, 2017, p. 107). Penelitian lainnya yang dilakukan pada atlet tingkat nasional di Indonesia menunjukan bahwa adanya hubungan antara asupan makan sehari-hari dengan profil somatotipe atlet pada bagian mesomorf (Penggalih, Juffrie, Sudargo, \& Sofro, 2017, p. 9). Apabila asupan makan belum bisa memenuhi kebutuhan atlet dengan tingkat aktivitas yang tinggi, maka pembentukan somatotipe tidak dapat maksimal dan dapat memberikan efek pada performa yang kurang optimal.

Berdasarkan studi dan kajian tersebut menjadi suatu dasar bagi penelitian ini untuk mengkaji nilai somatotipe, persen lemak tubuh dan pemenuhan tingkat asupan makan atlet. Hasil dari kajian ini dapat menjadi suatu evaluasi bagi atlet maupun official sehingga dapat dilakukan perbaikan yang akan memberikan efek positif terhadap prestasi atlet ke depan, mengingat atlet yang diikutsertakan dalam studi ini merupakan atlet profesional yang menjadi wakil Indonesia dalam ajang Sea Games 2017.

\section{METODE}

Penelitian ini menggunakan pendekatan deskriptif kuantitatif, dilakukan untuk identifikasi dan mengkaji nilai persen lemak tubuh, somatotype, dan pemenuhan asupan zat gizi makro (energi, karbohidrat, protein dan lemak).

Studi ini dilakukan pada bulan Desember 2016 kepada atlet difabel tenis meja yang sedang menjalani training centre di Solo. Pengukuran dan wawancara dilakukan dalam satu hari di Pusat Pengembangan dan Pelatihan Rehabilitasi Bersumberdaya Masyarakat (PPRBM) Solo, Indonesia. Penelitian ini di bawah supervisi Kementerian Pemuda dan Olahraga Republik Indonesia dengan nomor kode 092.01.06.3827.006.001.052.

Populasi dalam penelitian ini yaitu atlet difabel tenis meja di bawah pengawasan Kementerian Pemuda dan Olahraga, Indonesia yang sedang melakukan training centre untuk persiapan Sea Games 2017. Sampel yang diikutkan dalam penelitian ini yaitu seluruh populasi 
atlet difabel tenis meja nasional yang berjumlah 16 orang.

Penelitian ini menggunakan metode crosssectional dimana data didapatkan melalui pengukuran dalam satu waktu. Data antropometri yang diukur yaitu tinggi badan, berat badan, persen lemak tubuh dan somatotipe. Data pemenuhan asupan zat gizi didapatkan melalui wawancara makan dengan kuesioner recall 24 jam.

Pengumpulan data dilakukan dalam satu hari, selanjutnya data antropometri diolah dan dibandingkan dengan referensi. Data wawancara makan diolah dengan software nutrisurvey kemudian dibandingkan dengan kebutuhan zat gizi setiap individu untuk mendapatkan hasil persen pemenuhan. Kebutuhan zat gizi dihitung spesifik setiap individu berdasarkan tingkat aktivitas yang dilakukan setiap hari.

Kebutuhan energi atlet dihitung untuk mengetahui persentase pemenuhan asupan energi, protein, lemak dan karbohidrat. Perhitungan kebutuhan energi ini menggunakan faktor aktivitas 1,4 yaitu untuk aktivitas ringan. Energi basal diperoleh dari formulasi Harris-Benedict. Faktor koreksi terhadap masing-masing jenis disabilitas diperhitungkan dalam menghitung energi aktivitas. Energi latihan dihitung dari hasil anamnesis atlet yang disesuaikan dengan durasi dan frekuensi latihan spesifik setiap cabang olahraga.

Data antropometri meliputi variabel tinggi tubuh, berat tubuh, persen lemak tubuh dan somatotipe. Tinggi tubuh diukur menggunakan mikrotoa sedangkan data berat tubuh dan persen lemak menggunakan Karada Scan Body Impedance (BIA). Varibel somatotipe didapatkan dari pengukuran berat tubuh, tinggi tubuh, pengukuran skinfold pada lima titik (bisep, trisep, suprailliaka, subskapula dan betis), lingkar lengan tegang, lingkar betis dan pengukuran lebar tulang pada dua titik (humerus dan femur).

Pengukuran skinfold menggunakan alat Langenskinfold caliper, lebar tulang menggunakan Meiden's spreading caliper dan lingkar lengan serta betis menggunakan alat metlin. Keseluruhan pengukuran untuk somatotipe kemudian dikalkulasi untuk mendapatkan nilai somatotipe menggunakan rumus Heath \& Carter (Carter, Carter, \& Heath, 1990, p. 6) berikut:

1. Endomorf $=X$ (merupakan jumlah dari skinfold triceps, subscapula dan suprailliaca)

2. Mesomorf $=(0.858 \times$ lebar humerus $(\mathrm{cm}))+$ $(0.601 \times$ lebar femur $(\mathrm{cm}))+(0.188 \times$ lingkar lengan tegang $(\mathrm{cm}))-$ (skinfold triceps $(\mathrm{mm}) / 10)+(0.161 \times$ x (lingkar betis $(\mathrm{cm})-$ skinfold betis $(\mathrm{mm}) / 10))-(0.131 \times$ tinggi badan $(\mathrm{cm}))+45$

3. Ektomorf $=$ dihitung berdasarkan nilai height weight ratio (HWR: $\frac{\text { height }}{\sqrt[3]{\text { bodymass }}}$ ), kemudian nilai ektomorf dihitung dengan rumus:

a. (0.732 $\mathrm{x}$ HWR) apabila nilai HWR $>40.74$

b. $(0.463 \times \mathrm{HWR})$ apabila nilai $39.65<\mathrm{HWR}$ $\leq 40.74$

c. $(0.5 \times \mathrm{HWR})$ apabila nilai $\mathrm{HWR} \geq 39.65$

Keseluruhan data antropometri dianalisis dengan pendekatan deskriptif statistik dan disajikan dalam nilai rata-rata dan standar deviasi (SD). Data diolah menggunakan SPSS dan sebarannya normal. Data pemenuhan asupan makan disajikan dalam bentuk persen dan di-bandingkan tingkat pemenuhannya berdasarkan referensi (Wahyuningsih, 2013, p. 22).

\section{HASIL DAN PEMBAHASAN}

Tabel 1. Karakteristik Subjek

\begin{tabular}{|c|c|c|c|}
\hline No. & Karateristik & $\mathrm{N}$ & $\%$ \\
\hline \multirow[t]{7}{*}{1.} & Asal & & \\
\hline & a.Sumatera & 2 & 12,5 \\
\hline & b.Jawa & 9 & 56,25 \\
\hline & c.Sulawesi & 3 & 18,75 \\
\hline & d.Kalimantan & 1 & 6,25 \\
\hline & e.Papua & 1 & 6,25 \\
\hline & Total & 16 & 100 \\
\hline \multirow[t]{4}{*}{2.} & Jenis Kelamin & & \\
\hline & a.Laki-laki & 7 & 43,75 \\
\hline & b.Perempuan & 9 & 56,24 \\
\hline & Total & 16 & 100 \\
\hline \multirow[t]{6}{*}{3.} & Usia (tahun) & & \\
\hline & a. $17-25$ & 4 & 25 \\
\hline & b. $26-35$ & 4 & 25 \\
\hline & c. $36-45$ & 4 & 25 \\
\hline & d. $46-55$ & 4 & 25 \\
\hline & Total & 16 & 100 \\
\hline \multirow[t]{5}{*}{4.} & Jam tidur & & \\
\hline & a. $<8$ jam & 10 & 62,5 \\
\hline & b. 8 jam & 2 & 12,5 \\
\hline & c. $>8$ jam & 4 & 25,0 \\
\hline & Total & 16 & 100 \\
\hline \multirow[t]{6}{*}{5.} & Frekuensi bertand & & \\
\hline & a.Pemula & 2 & 12,5 \\
\hline & b. $1 \mathrm{kali} /$ tahun & 6 & 37,5 \\
\hline & c. 2 kali/tahun & 3 & 18,75 \\
\hline & d. 3 kali/tahun & 5 & 31,25 \\
\hline & Total & 16 & 100 \\
\hline
\end{tabular}

Nilai persen lemak total pada atlet (Tabel 2) yaitu $21 \%$ untuk laki-laki dan $29,6 \%$ untuk atlet perempuan. Penelitian oleh Munoz (2007, p.797) menuliskan rata-rata persen lemak total 
pada elit atlet tenis adalah $21,5 \%$ untuk laki-laki dan $33,1 \%$ untuk atlet perempuan. Apabila dibandingkan dengan studi tersebut maka dapat disimpulkan atlet NPC tenis meja memiliki persen lemak total yang lebih kecil.

Somatotipe atau bentuk tubuh adalah keadaan tubuh dari seseorang yang sangat menentukan aktivitas fisik terhadap suatu cabang olahraga tertentu (Hadisasmita \& Syarifuddin, 1996, p. 70). Menurut Sheldon yang dikutip oleh (Tóth, Michalíková, Bednarčíková, Živčák, \& Kneppo, 2014, p. 120), secara garis besar komponen somatotipe pada manusia manusia terdiri atas: (1) tipe endomorf yaitu tipe tubuh gemuk, (2) tipe mesomorf yaitu tipe tubuh yang besar dan kuat, dan (3) tipe ektomorf yaitu tipe tubuh yang kurus dan tinggi.

Ketiga komponen somatotipe tersebut merupakan perkembangan tahap organogenesis atau dikenal dengan proses pembentukan organ pada mahluk hidup. Organ yang terbentuk ini berasal dari lapisan dinding pada fase grastula. Lapisan dinding tersebut antara lain lapisan ektoderm yang akan berkembang menjadi jantung, otak, sistem saraf, jaringan kulit, rambut dan panca indera. Lapisan mesoderm akan berkembang menjadi otot, rangka tubuh, alat reproduksi, sistem peredaran darah dan sistem ekskresi tubuh. Lapisan terakhir yaitu endoderm akan berkembang menjadi sistem pencernaan dan respirasi (Hall, 2015, p. 11).
Setiap cabang olahraga mempunyai karakteristik yang berbeda dan masing-masing cabang olahraga memerlukan kesesuaian berdasarkan area dan pola permainan masingmasing. Pengukuran somatotipe biasanya diterapkan dalam proses penjaringan maupun pembibitan atlet. Rahmawati menyebutkan somatotipe atlet yang sesuai dengan cabang olahraga yang digeluti berpengaruh performa atlet tersebut (Rahmawati, 1996, p. 77).

Hasil pengukuran (Tabel 2) menunjukkan bahwa atlet tenis meja laki-laki memiliki tubuh yang lebih tinggi dan berotot, sedangkan atlet perempuan cenderung lebih banyak persentase lemak tubuh. Hal ini didukung dengan nilai persen lemak tubuh atlet perempuan dan komponen somatotipe bagian endomorf yang lebih tinggi, sedangkan komponen somatotipe mesomorf yang menunjukan otot lebih tinggi pada atlet laki-laki. Sebuah studi yang dilakukan oleh Zagatto (Zagatto, Kondric, Knechtle, Nikolaidis, \& Sperlich, 2018, p. 51) pada atlet tenis meja Brazil yang mengikuti kompetisi internasional dengan rata-rata usia 25,8 tahun dan 23,3 tahun untuk laki-laki dan perempuan menunjukan hasil persen lemak tubuh yang berbeda. Nilai persen lemak untuk atlet laki-laki adalah $12,6+2,9 \%$ sedangkan atlet perempuan $21,9 \pm 5,0 \%$. Berdasarkan referensi tersebut diketahui bahwa nilai persen lemak tubuh atlet laki-laki (21\%) dan perempuan $(29,6 \%)$ memiliki nilai yang lebih tinggi.

Tabel 2. Pengukuran Antropometri Atlet Difabel Tenis Meja

\begin{tabular}{llcccccc}
\hline \multirow{2}{*}{ No. } & \multirow{2}{*}{ Pengukuran } & \multicolumn{2}{c}{ Min } & \multicolumn{2}{c}{ Max } & \multicolumn{2}{c}{ Mean \pm SD } \\
\cline { 3 - 7 } & & Laki-laki & Perempuan & Laki-laki & Perempuan & Laki-laki & Perempuan \\
\hline 1. & Tinggi tubuh $(\mathrm{cm})$ & 163,6 & 131,0 & 172,0 & 164,7 & $167,2 \pm 3,2$ & $150,2 \pm 8,7$ \\
2. & Berat tubuh $(\mathrm{kg})$ & 45,5 & 41,0 & 77,5 & 66,1 & $64,8 \pm 10,0$ & $53,0 \pm 10,3$ \\
3. & Lemak tubuh (\%) & 16,6 & 20,5 & 24,3 & 38,7 & $21,0 \pm 3,1$ & $29,6 \pm 5,3$ \\
4. & Somatotipe & & & & & & \\
& a. Mesomorf & 4,7 & 4,1 & 7,5 & 7,8 & $6,3 \pm 1,1$ & $6,1 \pm 1,6$ \\
& b. Endomorf & 2,4 & 2,4 & 3,7 & 5,9 & $3,4 \pm 0,9$ & $4,6 \pm 1,6$ \\
& c. Ektomorf & 0,7 & 0,1 & 4,5 & 3,7 & $2,0 \pm 1,3$ & $1,4 \pm 1,3$ \\
\hline
\end{tabular}

Tabel 3. Hasil Interpretasi Nilai Somatotipe

\begin{tabular}{cccccccc}
\hline \multirow{2}{*}{ No. } & \multirow{2}{*}{ Interpretasi Somatotipe } & \multicolumn{2}{c}{ Laki-laki } & \multicolumn{2}{c}{ Perempuan } & \multicolumn{2}{c}{ Laki-laki dan Perempuan } \\
\cline { 3 - 7 } & & Jumlah & Persentase & Jumlah & Persentase & Jumlah & Persentase \\
\hline 1. & Endomorfik mesomorf & 6 & 85,7 & 6 & 66,7 & 12 & 75 \\
2. & Mesomorf - endomorf & 1 & 14.3 & 0 & 0 & 1 & 6,25 \\
3. & Endomorf - mesomorf & 0 & 0 & 2 & 22,2 & 2 & 12,5 \\
4. & Ektomorfik mesomorf & 0 & 0 & 1 & 11,1 & 1 & 6,25 \\
& Total & 7 & 100 & 9 & 100 & 16 & 100 \\
\hline
\end{tabular}


Jurnal Keolahragaan 6 (2), 2018 - 166

Mirza Hapsari Sakti Titis Penggalih, Kurnia Maratus Solichah, ...., Rora Asyulia

Tabel 4. Pemenuhan Asupan Zat Gizi Makro Atlet Difabel Tenis Meja

\begin{tabular}{clcccccc}
\hline \multirow{2}{*}{ No. } & \multirow{2}{*}{ Pengukuran } & \multicolumn{3}{c}{ Min } & \multicolumn{2}{c}{ Max } & \multicolumn{2}{c}{ Mean \pm SD } \\
\cline { 3 - 7 } 1. & Energi (\%) & 33 & 34 & 62 & 85 & $43,6 \pm 9,8$ & $54,4 \pm 17,8$ \\
2. & Karbohidrat (\%) & 24 & 20 & 50 & 88 & $38,1 \pm 9,7$ & $52,6 \pm 21,9$ \\
3. & Protein (\%) & 28 & 26 & 83 & 77 & $50,8 \pm 19,6$ & $54,6 \pm 18,5$ \\
4. & Lemak (\%) & 27 & 31 & 111 & 101 & $61,9 \pm 26,2$ & $74,5 \pm 22$ \\
\hline
\end{tabular}

Tabel 3 berisi informasi interpretasi nilai somatotipe dimana atlet tenis meja laki-laki dan perempuan dominan masuk dalam kategori endomorfik mesomorf. Diketahui kategori somatotipe ini memiliki nilai mesomorf yang paling dominan diantara ketiga komponen, selanjutnya diikuti oleh bagian endomorf. Meskipun secara rata-rata diketahui persentase lemak tubuh atlet perempuan lebih tinggi dari laki-laki namun interpretasi somatotipe menunjukan masih terdapat 1 atlet yang memiliki kategori somatotipe ektomorfik mesomorf, yaitu nilai ektomorf lebih dominan daripada endomorf. Hal ini menunjukkan bahwa pengukuran pada atlet selain melihat komponen persen lemak tubuh juga harus dilakukan pengukuran somatotipe supaya perbandingan antara lemak, otot dan tulang lebih rinci terlihat.

Penelitian yang dilakukan oleh Sepúlveda, Barraza, Soto, Báez, \& Tuesta (2015, p. 1691) pada atlet nasional tenis meja Chili dengan ratarata usia 21,6 tahun menunjukan nilai somatotipe 3,5-4,6-2,1 atau kategori mesomorf untuk atlet laki-laki. Sedangkan penelitian yang menunjukan nilai somatotipe untuk atlet tenis meja perempuan di atas usia 17 tahun belum ditemukan. SánchezMuñoz (Sánchez-Muñoz, Sanz, \& Zabala, 2007, p. 796) menuliskan nilai somatotipe 3,8-4,6-2,4 atau tipe mesomorf untuk atlet tenis meja perempuan namun pada usia 10-14 tahun. Kategori ini sesuai dengan referensi dari Sepúlveda (Sepúlveda et al., 2015, p. 1691) untuk atlet lakilaki, namun tidak dapat digunakan karena usia atlet yang tergolong masih muda sehingga ditakutkan terjadi bias apabila dibandingkan. Oleh karena itu pembahasan selanjutnya pada somatotipe difokuskan pada atlet tenis meja lakilaki.

Tipe somatotipe mesomorf yaitu nilai bagian mesomorf lebih dominan dari endomorf dan ektomorf (berbeda 1,5 poin dengan mesomorf). Rata-rata atlet laki-laki dan perempuan pada studi ini memiliki somatotipe kategori endomorfik mesomorf. Apabila ingin mencapai somatotipe kategori mesomorf, maka nilai endomorf harus berkurang dengan cara menurunkan nilai persentase lemak tubuh. Pelatih dapat menambahkan tipe latihan endurance yang disesuaikan dengan kemampuan setiap atlet untuk mengurangi persentase lemak tubuh.

Hasil lainnya yaitu nilai somatotipe bagian ektomorf lebih kecil jika dibandingkan dengan referensi (Sepúlveda et al., 2015, p. 1691). Hal ini disebabkan penggunaan kursi roda oleh atlet karena memiliki keterbatasan pada ekstremitas bagian bawah. Bagian kaki yang tidak pernah digunakan mengalami perubahan menjadi semakin kecil ukuran otot dan tulang. Selain itu lebar betis pada atlet difabel juga menjadi semakin kecil dikarenakan tidak mengalami perkembangan otot. Kondisi ini menyebabkan ketika dilakukan pengukuran lebar tulang humerus dan lingkar betis nilainya lebih kecil daripada pengukuran pada atlet normal dan memberikan efek pada nilai ektomorf.

Rata-rata pemenuhan asupan zat gizi makro (Tabel 4) pada atlet tenis meja laki-laki dan perempuan diketahui kurang dari $80 \%$. Interpretasi hasil pemenuhan asupan yang $<80 \%$ menurut Wahyuningsih masuk dalam kategori pemenuhan yang kurang (Wahyuningsih, 2013, p. 22). Melalui hasil wawancara didapatkan pemenuhan asupan makan yang kurang karena porsi makan atlet di bawah kebutuhan serta pemenuhan dari makanan selingan kurang.

Tenis meja masuk dalam cabang olahraga kategori net sport yang membutuhkan penguasaan keterampilan teknik dan kebugaran tubuh. Cabang olahraga ini juga membutuhkan daya ledak untuk menghadapi serangan yang muncul tiba-tiba sehingga membutuhkan energi yang adekuat untuk dapat melakukan performa yang maksimal (Brown \& Speed, 2013, p. 7).

Manusia memiliki dua macam tipe otot yaitu fast-twitch fibers dan slow-twitch fiber. Kedua tipe otot ini memiliki karakteristik berbeda, dan jumlah masing-masing tipe pada atlet sangat bervariasi utamanya ditentukan oleh jenis cabang olahraga yang digeluti. Otot jenis fast-twitch fiber memiliki ukuran diameter 2 kali lebih besar. Enzim yang membantu pelepasan energi melalu jalur phosphagen dan glikogenasam laktat lebih banyak ditemukan pada fasttwict fiber sehingga mampu untuk menghasilkan energi dalam kurun waktu yang lebih cepat 
daripada slow-twitch fiber. Slow-twitch fiber lebih berperan pada metabolisme energi aerob, sehingga jumlah mitokondria lebih banyak dan sangat menentukan endurance otot (Hall, 2015, p. 72).

Perbedaan kebutuhan zat gizi atlet tenis meja normal dengan difabel terletak pada perhitungan kebutuhan energi saat aktivitas. Kebutuhan energi diketahui terdiri dari 3 macam yaitu energi basal, latihan, dan aktivitas. Pada atlet difabel, perhitungan energi untuk aktivitas dikoreksi sesuai dengan jenis kecacatan yang dialami. Atlet yang menggunakan kursi roda energi untuk aktivitas akan berkurang 30\%. Sedangkan atlet yang mengalami spinal cord injury (SCI) berkurang 21\% (Croft, 2012, p. 5). Atlet yang mengalami amputasi hingga lutut energi untuk aktivitas akan meningkat 16-33\%, sedangkan atlet yang diamputasi hingga betis berkurang 56-65\% (Chin et al., 2005, p. 117). Hanada dan Kerrigan menyebutkan bahwa atlet yang mengalami amputasi satu tangan energi aktivitas sama dengan atlet normal, namun ketika kedua tangan diamputasi maka akan meningkat 5,6\% (Hanada \& Kerrigan, 2001, p. 1251).

Atlet tenis meja memiliki dua macam sistem energi yang terlibat yang berkaitan dengan jenis olahraga dan tipe otot yang digunakan saat kompetisi atau latihan. Sistem energi yang berlangsung saat pertandingan yaitu melalui anaerob. Hal ini disebabkan waktu pertandingan yang cepat sehingga tubuh memiliki waktu singkat untuk menghasilkan energi. Metabolisme energi anaerob melalui metabolisme glukosa dan glikogen menjadi laktat mampu menyediakan energi dalam waktu 3-4 detik (Gladden, 2003, p. 156).

Sistem energi kedua yang terlibat terutama pada fase pemulihan adalah sistem energi aerob melalui fosforilasi oksidatif. Saat fase pemulihan durasi latihan lebih lama daripada saat kompetensi, hal ini juga berkaitan dengan perbedaan jenis latihan sehingga memberikan tubuh waktu yang lebih lama untuk menghasilkan energi. Sub-strat utama yang digunakan dalam metabolisme aerob melalui fosforilasi oksidatif adalah karbohidrat, sehingga asupan karbohidrat yang cukup melalui makanan dapat memaksimalkan pembentukan energi (Gladden, 2003, p. 156).

Hughes (2002, p. 174) menyebutkan asupan karbohidrat yang adekuat perlu diperhatikan, baik pada masa prekompetisi maupun pascakompetisi. Karbohidrat menjadi sumber energi utama terutama untuk latihan dengan durasi lama. Karbohidrat yang dikonsumsi melalui makanan akan mulai diserap ketika berada di mulut dengan bantuan enzim $\alpha$-amylase. Pencernaan terus berlangsung sampai bolus memasuki lambung karena asam lambung menetralkan fungsi enzim amilase. Setelah melalui lambung, karbohidrat diserap kembali pada saluran pencernaan usus kecil oleh enzim yang sama (Gropper \& Smith, 2013, p. 55).

Glukosa hasil pemecahan karbohidrat dari makanan setelah diasbsorbsi oleh saluran pencernaan, selanjutnya akan dibawa menuju sel target untuk dijadikan bahan metabolisme energi. Komponen protein yang bertanggung jawab dalam membawa glukosa menuju sel target yaitu glucose transporter (GLUT). Terdapat berbagai macam jenis GLUT untuk membawa glukosa, disesuaikan dengan sel target. GLUT 4 berfungsi membawa glukosa menuju jaringan otot yang dipengaruhi oleh insulin (Gropper \& Smith, 2013, p. 56).

Deplesi simpanan karbohidrat di otot dapat mengakibatkan kelelahan otot secara cepat sehingga berpengaruh terhadap daya tahan atau endurance, baik saat latihan maupun kompetisi (Skolnik \& Chernus, 2010, p. 23). Asupan karbohidrat yang adekuat setelah pertandingan sangat diperlukan untuk proses recovery dan optimalisasi simpanan glikogen di otot dan hati (Maughan, 2008, p. 112). Optimalisasi ini dapat dicapai dengan menjaga asupan karbohidrat baik jenis dan jumlah harian atlet selama latihan dan pertandingan. Pemenuhan ini bertujuan untuk melakukan pengisian karbohidrat (carbohydrate loading), yaitu pengaturan diet karbohidrat sehingga glikogen otot dapat terbentuk dan ditimbun dengan cara tujuh hari sebelum pertandingan dilakukan latihan yang berat selama tiga hari untuk menguras simpanan glikogen, selanjutnya diet yang diberikan pada hari ke-2 hingga ke-4 konsumsi rendah karbohidrat, tinggi lemak dan protein untuk memenuhi kebutuhan energi, namun mencegah pengisian glikogen. Kemudian pada hari ke 5-7 sebelum bertanding diberikan diet tinggi karbohidrat (70-75\% dari total energi) untuk memaksimalkan glikogen otot yang telah terkuras sebelumnya. Pada masa ini intensitas dan lama latihan dikurangi untuk menurunkan penggunaan glikogen otot dan menjamin simpanan yang maksimal pada hari pertandingan. Teknik ini dapat meningkatkan cadangan glikogen dari kadar normal (80-100 mmol/kgBB) menjadi $200 \mathrm{mmol} / \mathrm{kgBB}$ (Sherman, Doyle, Lamb, \& Strauss, 1993, p. 31). 
Asupan protein perlu diperhatikan berkaitan dengan pembentukan otot yang memberikan kekuatan dan kecepatan gerakan pada saat berolahraga. Kurangnya asupan protein dapat menghambat pembentukan otot-otot tubuh dan pada proses recovery apabila tidak memiliki asupan protein yang cukup dapat menurunkan performa karena tingginya proses pelepasan protein otot tidak didukung dengan penggantian kembali zat tersebut di otot (Driskell \& Wolinsky, 2011, p. 256). Selain itu asupan protein yang cukup membantu menjaga simpanan glikogen otot yang pada saat pertandingan akan digunakan dalam metabolisme anaerob untuk menghasilkan energi (Gladden, 2003, p. 157).

Pembentukan massa otot ditentukan oleh net protein balance atau lebih dikenal dengan NBAL. Keseimbangan NBAL menuju arah positif menunjukan terjadi pertumbuhan massa otot sedangkan nilai negatif pada keseimbangan NBAL mengindikasikan terjadi penurunan massa otot. Keseimbangan NBAL ini sangat dipengaruhi oleh makanan yang dikonsumsi terutama jenis protein dan karbohidrat serta aktifitas fisik yang dilakukan (Tripton, 2008). Kontribusi protein terhadap kebutuhan energi atlet tidak mencapai $10 \%$ atau $15 \%$ atau dapat dikatakan kebutuhan protein sekitar 1,2-1,6 gr per kilogram berat tubuh (Gibala, Hargreaves, \& Tipton, 2000, p. 4).

Pembentukan otot dipengaruhi oleh aktivitas fisik selain jumlah protein yang dikonsumsi. Olahraga atau aktivitas fisik menginduksi biogenesis mitokondria di dalam sel otot dan meningkatkan sintesis protein melalui ekspresi gen. Aktivasi sinyal mTORC1 pada ekspresi gen distimulasi oleh jenis asam amino tertentu yaitu branch chain amino acid (BCAA) (Moberg, 2016, p. 125).

Intake protein yang dikonsumsi oleh atlet diketahui memberikan efek pada massa bebas lemak terutama massa otot. Beberapa penelitian menunjukan pengaruh protein pada tekanan darah atlet dengan berbagai macam cabang olahraga. Stamler et al. (1996, p. 1629) menuliskan pada studinya bahwa tekanan darah sistole dan diastole turun 3 dan $2,5 \mathrm{mmHg}$ pada individu yang memiliki intake protein lebih tinggi di atas rata-rata. Appel (2003, p.55) meneliti lebih lanjut jenis protein yang mampu menurunkan tekanan darah yaitu jenis protein nabati. Jenis protein nabati yang digunakan pada penelitian tersebut yaitu kedelai. (Elliott et al., 2006, p. 79) menguatkan temuan sebelumnya, yaitu bahwa jenis protein nabati mampu menurunkan tekanan darah secara signifikan, sedangkan protein hewani dan intake protein campuran (nabati dan hewani) mampu menurunkan tekanan darah namun belum mencapai angka signifikansi ketika diuji dengan statistik.

Lemak secara cukup berfungsi sebagai sumber energi setelah karbohidrat, tetapi penggunaannya sebagai sumber energi utama dapat menurunkan performa dan mempercepat kelelahan (Brouns, 2002). Konsumsi tinggi lemak (>30\% total kalorti) dapat menurunkan asupan karbohidrat yang memberikan efek penurunan glikogen. Selain itu asupan tinggi lemak akan menyebabkan obesitas, meningkatkan risiko jantung koroner, stroke dan kanker. Anjuran proporsi asupan lemak adalah 20-30\% dari total jumlah kebutuhan kalori (Coggan, Coleman, Hopkins, \& Spriet, 1996).

Komponen utama dalam metabolisme oksidatif atau aerob adalah karbohidrat, protein dan lemak yang dikonsumsi sehari-hari. Saat otot berkontraksi selama 2-4 jam, setengah energi yang dibutuhkan didapatkan dari pemecahan simpanan karbohidrat. Dasar inilah yang dijadikan patokan aturan jam pemberian makan pada atlet. Aturan pemberian makanan pada atlet ini dapat dipenuhi sebagai berikut.

a. Total energi intake adalah $45-60 \mathrm{kcal} / \mathrm{kgBB}$ per hari atau sekitar 3100-4200 kcal/hari.

b. Asupan karbohidrat dan cairan saat latihan rutin adalah 8-10 g/kgBB atau sekitar 60-70\% total kalori. Minum cukup cairan untuk mencegah dehidrasi. Jika urin berwarna keruh hal ini dapat diartikan kekurangan cairan.

c. Makanan sebelum bertanding: pertama, Dilakukan 3-4 jam sebelum tanding. 60-70\% kalori makanan berasal dari karbohidrat dengan jenis yang mudah dicerna. Kedua, Hindari makanan tinggi lemak seperti gorengan. Makanan jenis ini tidak mudah dicerna dan menimbulkan ketidak nyamanan lambung. Ketiga, Hindari makanan berserat tinggi karena dapat menyebabkan kram perut dan kembung. Keempat, Lebih diperhatikan makanan cair jika dalam kondisi sakit dan tidak enak tubuh. Kelima, Minum minuman karbohidrat 2-4 gelas 2 jam sebelum tanding dan ditambah 1-2 gelas 15-20 menit tepat sebelum tanding. Keenam, Rehidrasi cairan untuk prolonged exercise yaitu $150 \mathrm{ml}$ setiap 15 menit (Convertino et al., 1996, p. vii).

d. Makanan selama pertandingan: Minum minuman yang mengandung gula dan elektrolit saat ada waktu minimal tiap 10-20 menit pertandingan. 
e. Makanan setelah pertandingan, yaitu, pertama Segera setelah bertanding konsumsi cairan elektrolit dan karbohidrat untuk rehidrasi cairan tubuh. 1 gr karbohidrat per $\mathrm{kg} / \mathrm{BB}$. Kedua, Air yang diminum pasca latihan untuk rehidrasi cairan yaitu $1400 \mathrm{ml}$ untuk setiap 1 $\mathrm{kg}$ berat tubuh yang hilang (Pfeiffer, Mangus, \& Trowbridge, 2014, p. 63). Ketiga, setelah 24 jam selesai tanding kembalikan pola makan harian dengan 8-10 gr/kgBB.

Daly, Bass, Caine, \& Howe (2002, p. 21) menuliskan pada studinya bahwa atlet dewasa memiliki resiko terhadap pertumbuhan dan penundaan kematangan saat latihan maupun kompetisi jika mengalami kekurangan asupan energi dalam jangka waktu yang lama. Keadaan ini dapat disebabkan karena kurangnya pengetahuan untuk memilih dan mencukupi kebutuhan zat gizi melalui makanan (Rosenbloom, 2000, p. 15). Rash, Malinauskas, Duffrin, Barber-Heidal, \& Overton (2008, p. 48) menyebutkan bahwa pengetahuan yang berkaitan dengan gizi mempengaruhi sebesar 5\% dari asupan makan seharihari sehingga masih terdapat faktor lain yang mempengaruhi tingkat pemenuhan zat gizi atlet antara lain pemilihan menu makanan yang disediakan oleh asrama tempat atlet tinggal. Mengingat responden pada penelitian ini tinggal 24 jam di asrama, sehingga siklus menu yang diberlakukan juga dapat memengaruhi.

\section{SIMPULAN}

Persen lemak tubuh atlet tenis meja difabel di Indonesia masuk dalam kategori berlebih. Persen lemak berlebih terutama terdapat pada bagian lengan dan badan. Hal ini berkaitan dengan disabilitas atlet pada kaki sehingga menggunakan kursi roda sehingga aktivitas fisik pada bagian lengan dan badan terbatas. Pengukuran somatotipe menunjukkan kategori somatotipe atlet laki-laki dan perempuan belum sesuai dengan referensi yang diambil disebabkan karena pengukuran ini ditujukan untuk perawakan tubuh yang sempurna sedangkan pada atlet difabel memiliki kekurangan fisik tertentu. Pemenuhan asupan energi dan zat gizi makro pada atlet tenis meja laki-laki dan perempuan < $80 \%$ sehingga masih masuk dalam kategori pemenuhan asupan makan yang kurang.

Atlet dan tim official dapat meningkatkan intensitas, durasi maupun frekuensi aktivitas fisik mengingat hasil pengukuran persen lemak tubuh atlet masuk dalam kategori berlebih. Jenis aktivitas fisik yang bisa dilakukan untuk atlet dengan kursi roda yaitu latihan pembebanan dengan tujuan pembakaran lemak pada bagian lengan dan badan. Selanjutnya porsi makan atlet sebaiknya ditingkatkan terutama pada sumber protein untuk membantu peningkatan massa otot serta karbohidrat dan energi sebagai penyedia sumber tenaga saat beraktivitas.

\section{DAFTAR PUSTAKA}

Brown, F., \& Speed, C. (2013). Assessing nutritional knowledge and supplementation practices in elite badminton players. British Journal of Sports Medicine, 47(17), e4.16-e4. https://doi.org/10.1136/bjsports-2013093073.23

Carter, J. E. L., Carter, J. E. L., \& Heath, B. H. (1990). Somatotyping: development and applications. Cambridge, MA: Cambridge University Press.

Chin, T., Sawamura, S., Shiba, R., Oyabu, H., Nagakura, Y., \& Nakagawa, A. (2005). Energy expenditure during walking in amputees after disarticulation of the hip. The Journal of Bone and Joint Surgery. British Volume, 87-B(1), 117-119. https://doi.org/10.1302/0301620X.87B1.14617

Coggan, A., Coleman, E., Hopkins, W., \& Spriet, L. (1996). Dietary fat and physical activity: Fueling the controversy. Sports Science Exchange, 7(3).

Convertino, V. A., Armstrong, L. E., Coyle, E. F., Mack, G. W., Sawka, M. N., Senay, L. C., \& Sherman, W. M. (1996). Exercise and fluid replacement. Medicine \& Science in Sports \& Exercise, 28(1), 377-390. https://doi.org/10.1249/mss.0b013e31802 ca597

Croft, L. (2012). Investigating energy expenditure in wheelchair athletes. (C) L.E. Croft. Retrieved from https://dspace.lboro.ac.uk/dspacejspui/handle/2134/9788

Daly, R. M., Bass, S., Caine, D., \& Howe, W. (2002). Does training affect growth? The Physician and Sportsmedicine, 30(10), 21-29.

https://doi.org/10.3810/psm.2002.10.488

Driskell, J. A., \& Wolinsky, I. (2011). Nutritional assessment of athletes. CRC Press.

Elliott, P., Stamler, J., Dyer, A. R., Appel, L., Dennis, B., Kesteloot, H., ... Zhou, B. 
(2006). Association between protein intake and blood pressure. Archives of Internal Medicine, $\quad 166(1)$, 79. https://doi.org/10.1001/archinte.166.1.79

Gibala, M. J., Hargreaves, M., \& Tipton, K. (2000). Amino acids, proteins, and exercise performance. Sports Sci Exchange Roundtable, 42(11), 4.

Gladden, L. B. (2003). Lactate metabolism during exercise. In Principles of Exercise Biochemistry (Vol. 46, pp. 152-196). Basel: KARGER. https://doi.org/10.1159/000074368

Gropper, S. A. S., \& Smith, J. L. (2013). Advanced nutrition and human metabolism. Wadsworth/Cengage Learning.

Hadisasmita, Y., \& Syarifuddin, A. (1996). Ilmu kepelatihan dasar. Jakarta: Departemen Pendidikan dan Kebudayaan.

Hall, J. E. (2015). Guyton and Hall textbook of medical physiology.

Hanada, E., \& Kerrigan, D. C. (2001). Energy consumption during level walking with arm and knee immobilized. Archives of Physical Medicine and Rehabilitation, 82(9), 1251-1254.

Hughes, M. (2002). The application of notational analysis to racket sports. In Science and Racket Sports II (pp. 229-238). Taylor \& Francis.

Kovacs, M. S. (2007). Tennis physiology: Training the competitive athlete. Sports Medicine, 37(3), 189-198. https://doi.org/10.2165/00007256200737030-00001

Limoochi, S. (2012). A survey of table tennis coache's opinions of some criteria in talent identification. European Journal of Sports \& Exercise Science, 2(2), 18-23. Retrieved from https://www.scholarsresearchlibrary.com/ abstract/a-survey-of-table-tennis-coachesopinions-of-some-criteria-in-talentidentification-7815.html

Maughan, R. J. (2008). Nutrition in sport. John Wiley \& Sons.

Moberg, M. (2016). Effects of exercise and amino acid intake on mechanisms regulating protein synthesis and breakdown in human muscle. Gymnastik- och idrottshögskolan.

Penggalih, M. H. S. (2017). Efektivitas penatalaksanaan gizi pada atlet terhadap perbaikan status gizi sebagai penunjang performa (Kajian pada atlet sepakbola remaja). Universitas Gadjah Mada. Retrieved from http://etd.repository.ugm.ac.id/index.php? mod=penelitian_detail\&sub=PenelitianDe tail\&act=view\&typ=html\&buku_id=1118 28\&obyek_id=4

Penggalih, M. H. S., Juffrie, M., Sudargo, T., \& Sofro, Z. M. (2017). Correlation between dietary intake with anthropometry profile on youth football athlete in Indonesia. Asian Journal of Clinical Nutrition, 9(1), 9-16. https://doi.org/10.3923/ajen.2017.9.16

Pfeiffer, R. P., Mangus, B. C., \& Trowbridge, C. A. (2014). Concepts of athletic training. Jones \& Bartlett Publishers.

Rahmawati, N. T. (1996). Beberapa ukuran antropometri pada atlet sepakbola dan bulutangkis di Yogyakarta. Journal of the Medical Sciences (Berkala Ilmu Kedokteran), 28(2). Retrieved from https://jurnal.ugm.ac.id/bik/article/view/4 343

Rash, C. L., Malinauskas, B. M., Duffrin, M. W., Barber-Heidal, K., \& Overton, R. F. (2008). Nutrition-related knowledge, attitude, and dietary intake of college track athletes. The Sport Journal, 11(1), 48-54. Retrieved from https://thesportjournal.org/article/nutrition -related-knowledge-attitude-and-dietaryintake-of-college-track-athletes/

Rosenbloom, C. (2000). Sports nutrition: A guide for the professional working with active people. The American Dietetic Association.

Sánchez-Muñoz, C., Sanz, D., \& Zabala, M. (2007). Anthropometric characteristics, body composition and somatotype of elite junior tennis players. British Journal of Sports Medicine, 41(11), 793-799.

Sepúlveda, R. Y., Barraza, F., Soto, G. R., Báez, E., \& Tuesta, M. (2015). Anthropometric Chilean table tennis players of competitive features. Nutricion Hospitalaria, 32(4), 1689-1694.

https://doi.org/10.3305/nh.2015.32.4.9547

Sherman, W. M., Doyle, J. A., Lamb, D. R., \& Strauss, R. H. (1993). Dietary carbohydrate, muscle glycogen, and 


\section{Jurnal Keolahragaan 6 (2), 2018 - 171}

Mirza Hapsari Sakti Titis Penggalih, Kurnia Maratus Solichah, ...., Rora Asyulia

exercise performance during $7 \mathrm{~d}$ of training. The American Journal of Clinical Nutrition, $57(1)$ $27-31$. https://doi.org/10.1093/ajen/57.1.27

Skolnik, H., \& Chernus, A. (2010). Nutrient timing for peak performance. Human Kinetics.

Stamler, J., Elliott, P., Kesteloot, H., Nichols, R., Claeys, G., Dyer, A. R., \& Stamler, R. (1996). Inverse relation of dietary protein markers with blood pressure. Circulation, 94(7), 1629-1634. https://doi.org/10.1161/01.CIR.94.7.1629

Tóth, T., Michalíková, M., Bednarčíková, L., Živčák, J., \& Kneppo, P. (2014).
Somatotypes in sport. Acta Mechanica et Automatica, 8(1), 27-32. Retrieved from https://content.sciendo.com/view/journals/ ama/8/1/article-

p27.xml?rskey $=7 \mathrm{AW} 16 \mathrm{~b} \&$ result $=1$

Wahyuningsih, R. (2013). Penatalaksanaan diet pada pasien. Yogyakarta: Graha Ilmu.

Zagatto, A. M., Kondric, M., Knechtle, B., Nikolaidis, P. T., \& Sperlich, B. (2018). Energetic demand and physical conditioning of table tennis players. A study review. Journal of Sports Sciences, 36(7), 724-731. https://doi.org/10.1080/02640414.2017.13 35957 